\title{
Research of the Influence of Impurities on the Occurrence of Intermetallic Phases in AlMg3 Alloy
}

Iryna Hren, Štefan Michna, Jaromír Cais, Lenka Michnová

Faculty of Mechanical Engineering, J. E. Purkyne University in Usti nad Labem. Pasteurova 3334/7, 40001 Usti nad Labem. Czech Republic. E-mail: iryna.hren@ujep.cz, stefan.michna@ujep.cz, jaromir.cais@ujep.cz, lenka.michnova@ujep.cz

The main aim of this work was to investigate the influence of impurities on the occurrence of intermetallic phases in AlMg3 alloy. The effect of accompanying (admixture) elements was studied, namely: manganese, iron and silicon in various combinations of AlMg3 alloy. There was a high manganese content in one melt for AlMg3, a high iron and manganese content in the second, and a high manganese, iron and silicon content in the third. The reason for identifying and monitoring the occurrence of intermetallic phases in these accompanying elements is their limited solubility in aluminum, where they are practically secreted only in the form of different types of intermetallic phases. These intermetallic phases then reduce the resulting mechanical properties, especially ductility of the AlMg3 alloy. Decrease of ductility causes consequently worse formability of the material and brittle intermetallic phases initiate microcracks with subsequent cracking of the material.

Keywords: AlMg3 alloy, intermetallic phases, manganese, iron, silicon, strength, ductility, chemical composition, EDS analysis.

\section{Introduction}

The physical, chemical, mechanical and other properties of aluminum and aluminum alloys are greatly influenced by the purity of the input materials, the melting, casting and forming technology used. Therefore, it is necessary to know the basic thermodynamic characteristics of aluminum. The most common binary aluminum alloys are binary systems such as $\mathrm{Al}-\mathrm{Cu}, \mathrm{Al}-\mathrm{Mg}, \mathrm{Al}-\mathrm{Mn}, \mathrm{Al}-\mathrm{Si}, \mathrm{Al}-\mathrm{Zn}$. In these systems, aluminum with the corresponding elements forms a substitute solid solution $\alpha$ which, with good formability and toughness, has better mechanical properties than pure aluminum. The maximum solubility of the admixtures in solid $\mathrm{Al}$ solution is at eutectic temperature. As the temperature decreases, the solubility of the ingredients decreases and at room temperature it is small or negligible. The equilibrium binary diagrams on the aluminum side are mostly of the simple eutectic or peritectic type. At higher additive concentrations the diagrams are complicated by the formation of intermetallic phases $(\mathrm{Cu}, \mathrm{Mg}, \mathrm{Mn}$ additives) or they are simple diagrams with limited solid solubility of both components (Al - Si system).

$\mathrm{Al}$ - Mg binary alloys are the basis of an important group of unconsolidated alloys. Although magnesium dissolves in considerable amounts in a solid aluminum solution from about 17.4 wt. $\%$ at $450{ }^{\circ} \mathrm{C}$ up to a concentration of 1.9 wt. $\% \mathrm{Mg}$ at $200^{\circ} \mathrm{C}$, which induces phase $\beta\left(\mathrm{Al}_{3} \mathrm{Mg}_{2}\right)$ segregation in all technical alloys, in binary alloys the effect of dispersion hardening (aging) at concentrations of less than $7 \mathrm{wt} . \% \mathrm{Mg}$. Magnesium significantly improves the mechanical properties of aluminum alloys. The strength with the addition of magnesium gradually increases, the ductility initially decreases and only slightly increases from $3 \mathrm{wt} . \% \mathrm{Mg}$. However, the magnesium content of the forming alloys is not more than $7 \%$ by weight. This is because alloys with higher $\mathrm{Mg}$ content have worse corrosion resistance and especially worse formability. Compound $\mathrm{Al}_{3} \mathrm{Mg}_{2}$, which is secreted at grain boundaries, is prone to corrosion [1].

The equilibrium phase diagram of the $\mathrm{Al}$ - Mg system in Fig. 1. The equilibrium solid phases in the $\mathrm{Al}$ $\mathrm{Mg}$ system are: KPC (Al) solid solution with a maximum solubility of 18.9 at. $\% \mathrm{Mg}$ in $(\mathrm{Al})$ at a eutectic temperature of $450^{\circ} \mathrm{C}$; HTU $(\mathrm{Mg})$ solid solution with a maximum solubility of 11.8 at. $\% \mathrm{Al}$ in $(\mathrm{Mg})$ at a eutectic temperature of $437^{\circ} \mathrm{C}$; compound with approximate stoichiometry of $\mathrm{Al}_{3} \mathrm{Mg}_{2}$ and complex $\mathrm{KPC}$ structure (martensitic transformation $\beta$ occurs at low temperatures to another structure, eg. by deform $\beta$ phase deformation, but equilibrium phase ratios have not been investigated yet); Compound R (often referred to as $\varepsilon$ ) having a composition corresponding to 42 at. $\% \mathrm{Mg}$ and Compound with a enzmartensitic structure (at $450{ }^{\circ} \mathrm{C}$, phase $\gamma$ has a maximum coexistence range of approximately 45 to $60.5 \mathrm{at} . \% \mathrm{Mg}$, but ideal crystalline structure has stoichiometry Al12Mg17 at 58.6 at. $\% \mathrm{Mg}$ ) [2-5]. Phase $\beta$ occurs as stable at 38.6 - 40.4 at. $\% \mathrm{Mg}$. The phase boundaries in the given $\mathrm{Al}$ - Mg diagram were also obtained by thermodynamic 
calculations outside the single - phase $\beta$ regions. The current diagram is based on a review of a number of works, the more recent ones [6-8] and [9].

Equilibrium crystallization can only be observed at cooling rates less than 5.10-6 K/ h. Under conditions of non-equilibrium crystallization, dendritic liquidation with $\mathrm{Al}_{3} \mathrm{Mg}_{2}$ phase formation occurs even at low magnesium contents of $4 \div 5 \mathrm{wt} . \%$. This phase is very brittle at temperatures below $350{ }^{\circ} \mathrm{C}$, becomes more plastic at higher temperatures and, after crystallization, is eliminated at the dendritic boundaries [10-13].

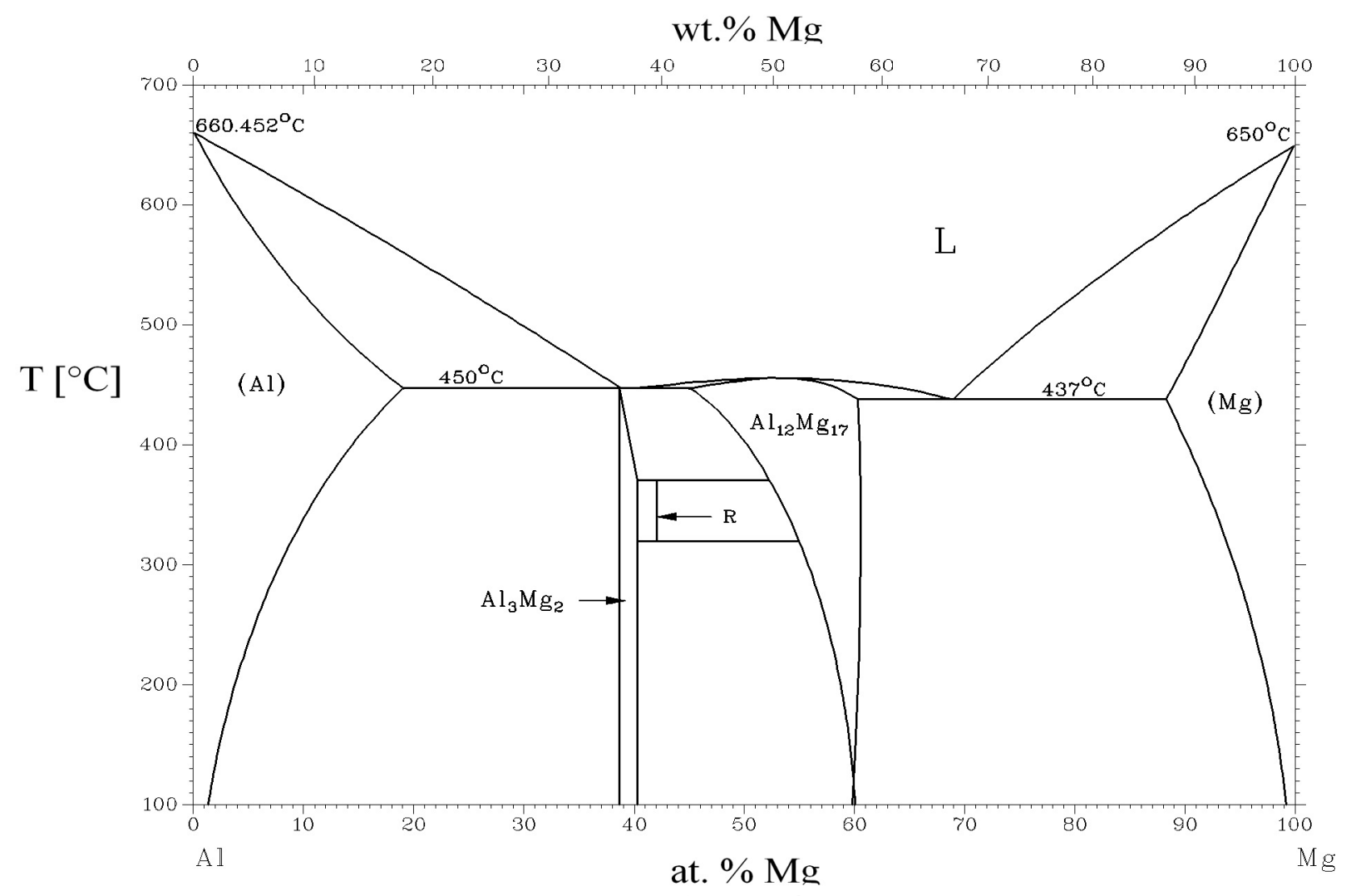

Fig. 1 Binary diagram $\mathrm{Al}-\mathrm{Mg}$

The presented experiment is part of a larger research focused on the study of AlMg3 alloy. This alloy was invented by the Faculty of Mechanical Engineering of UJEP and has never been studied in a similar study. The aim of this work was to investigate and analyze the individual phases that were identified in the structure of the AlMg3 alloy. Improving the quality of the material and eliminating defects can be done by examining all the factors affecting the casting process and material production, such as mapping the occurrence of intermetallic phases in the alloy structure.

\section{Experiment}

An AlMg3 alloy was specially developed and produced for the experiment with different content of (admixture) elements were selected for research: manganese, iron and silicon in various combinations. There was a high manganese content in one of the AlMg3 alloys, a high iron, manganese and chromium in the other, and a high manganese, iron, silicon and manganese content in the third. Also one melt with low $\mathrm{Mn}, \mathrm{Fe}, \mathrm{Si}$ and $\mathrm{Cr}$ content was selected. The chemical composition of all melts was performed by using a spectrometer Q4 TASMAN and is given in Table 1 . The reason for identifying and monitoring the occurrence of intermetallic phases in these accompanying elements is their limited solubility in aluminum, where they are practically secreted only in the form of different types of intermetallic phases. These intermetallic phases then reduce the resulting mechanical properties (strength, ductility) and also reduce the corrosion resistance of the AlMg3 alloy.

Sample identification:

Sample No. 1 - with a higher content of Mn, Fe and $\mathrm{Si}$

Sample No. 2 - with high Fe content and higher $\mathrm{Mn}, \mathrm{Si}$ and $\mathrm{Cr}$ content

Sample No. 3 - with a high content of $\mathrm{Mn}, \mathrm{Si}, \mathrm{Cr}$ and a very high Fe content

Sample No. 4 - with very low Mn, Fe, Si and Cr content

The chemical composition of each supplied sample is given in Table 1. 
Tab. 1 Chemical composition of sheet samples No. 1 - 4, [wt. \%]

\begin{tabular}{|c|c|c|c|c|c|c|c|c|c|c|}
\hline Sample No. & $\mathrm{Si}$ & $\mathrm{Fe}$ & $\mathrm{Cu}$ & $\mathrm{Mn}$ & $\mathrm{Mg}$ & $\mathrm{Cr}$ & $\mathrm{Ni}$ & $\mathrm{Zn}$ & $\mathrm{Ti}$ & $\mathrm{Al}$ \\
\hline 1 & 0.117 & 0.425 & 0.019 & 0.319 & 2.780 & 0.045 & 0.0058 & 0.027 & 0.032 & 96.14 \\
\hline 2 & 0.118 & 0.716 & 0.018 & 0.214 & 3.109 & 0.155 & 0.051 & 0.027 & 0.019 & 95.51 \\
\hline 3 & 0.125 & 0.710 & 0.018 & 0.214 & 3.198 & 0.160 & 0.049 & 0.029 & 0.019 & 95.42 \\
\hline 4 & 0.069 & 0.231 & $<0.0010$ & 0.068 & 2.656 & $<0.002$ & $<0.002$ & 0.014 & 0.009 & 96.87 \\
\hline
\end{tabular}

The sample No. 4 shows a low iron and manganese content compared to samples No. 1, 2, 3 in the sum of up to $2 \mathrm{x}-3 \mathrm{x}$ currency when comparing the chemical composition of individual samples. Samples No. 2 and 3 contain such an increased amount of chromium compared to the other samples.

\section{Microscopic evaluation of the structure}

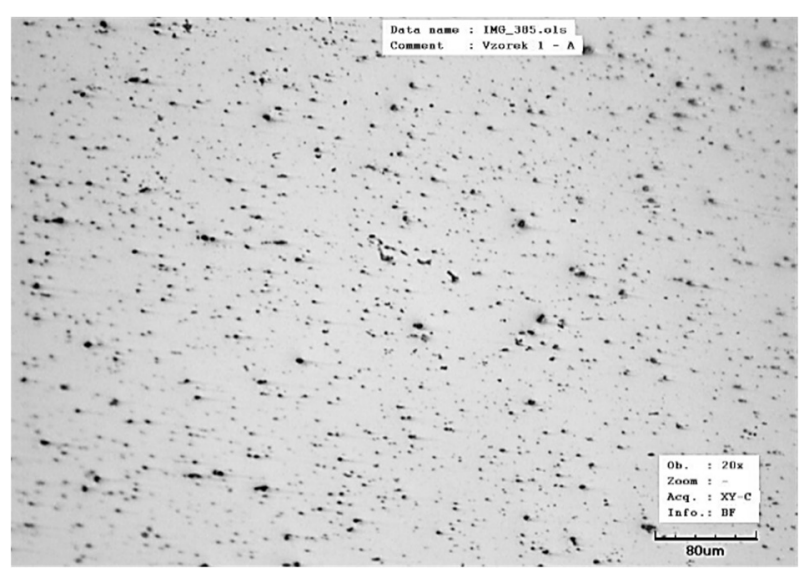

Fig. 2 Sheet metal microstructure (perpendicular to the rolling direction), mag. 200x

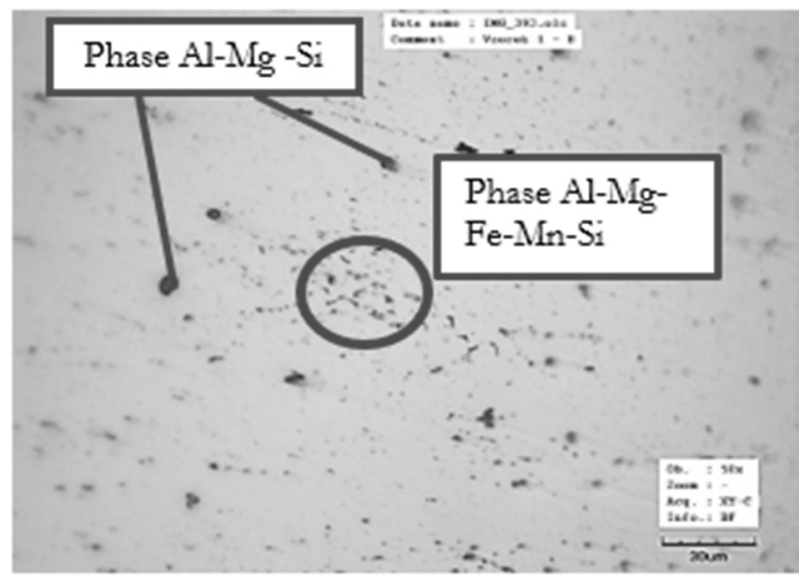

Fig. 3 Sheet metal microstructure (perpendicular to the rolling direction), mag. $500 x$

An Olympus LEXT OLS 3100 confocal laser microscope was used to examine the samples. Figure 2 captures the microstructure of a sample formed of sheet metal in the rolling direction. In the microstructure of samples made of sheet metal, 3 types of phases were recognized by optical microscopy. Very fine gray phases occurring evenly over the entire cross-section of the sample are $\mathrm{Al}-\mathrm{Mg}$-based intermediate phases. Another identified intermetallic phase in the microstructure of the sample is the intermediate phase based on Al-Mg-Fe-Mn-Si. The third type of phase recognized in the microstructure is the $\mathrm{Al}-\mathrm{Mg}$-Si-based intermediate phase. This phase appears dark gray or black in the optical microscope images (indicated in Fig. 3).

\section{EDS analysis of individual intermetallic phases in samples}

A Tescan VEGA 3 scanning electron microscope fitted with a Bruker EDS analyzer was used to generate electron microscopy images. The analysis of these samples focused on the recognition of possible intermetallic phases occurring in the solid solution within the material.

\section{Sample 1}

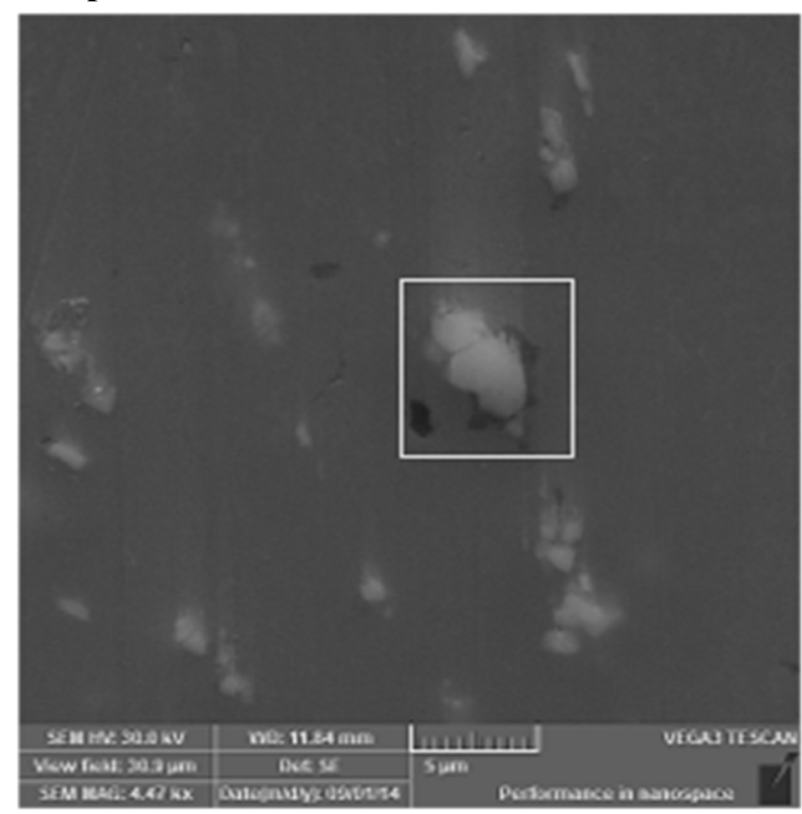

Fig. 4 Detail of analyzed intermetallic phase of sample No.1

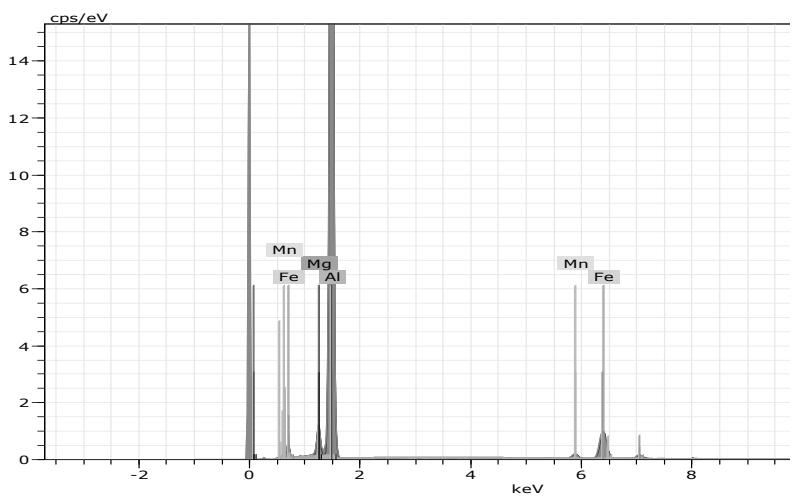

Fig. 5 Spectrum of EDS analysis from sample No. 1 
Tab. 2 Quantification of areal EDS analysis from samples No.1 (area marked in Fig. 2)

\begin{tabular}{|c|c|c|c|c|c|}
\hline 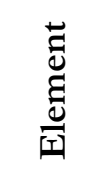 & $\cdot \stackrel{\mathscr{D}}{\mathscr{D}}$ & 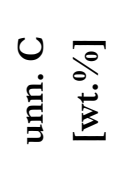 & 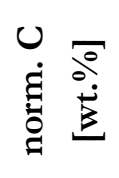 & $\begin{array}{ll}u \\
\dot{g} \\
\stackrel{+}{*}\end{array}$ & 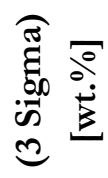 \\
\hline $\mathrm{Al}$ & K-series & 93.76 & 86.84 & 91.26 & 14.21 \\
\hline $\mathrm{Fe}$ & K-series & 9.62 & 8.91 & 4.52 & 0.91 \\
\hline $\mathbf{M g}$ & $\mathrm{K}$-series & 3.36 & 3.11 & 3.63 & 0.72 \\
\hline Mn & K-series & 1.23 & 1.14 & 0.59 & 0.24 \\
\hline Total: & & 107.96 & 100.00 & 100.00 & \\
\hline
\end{tabular}

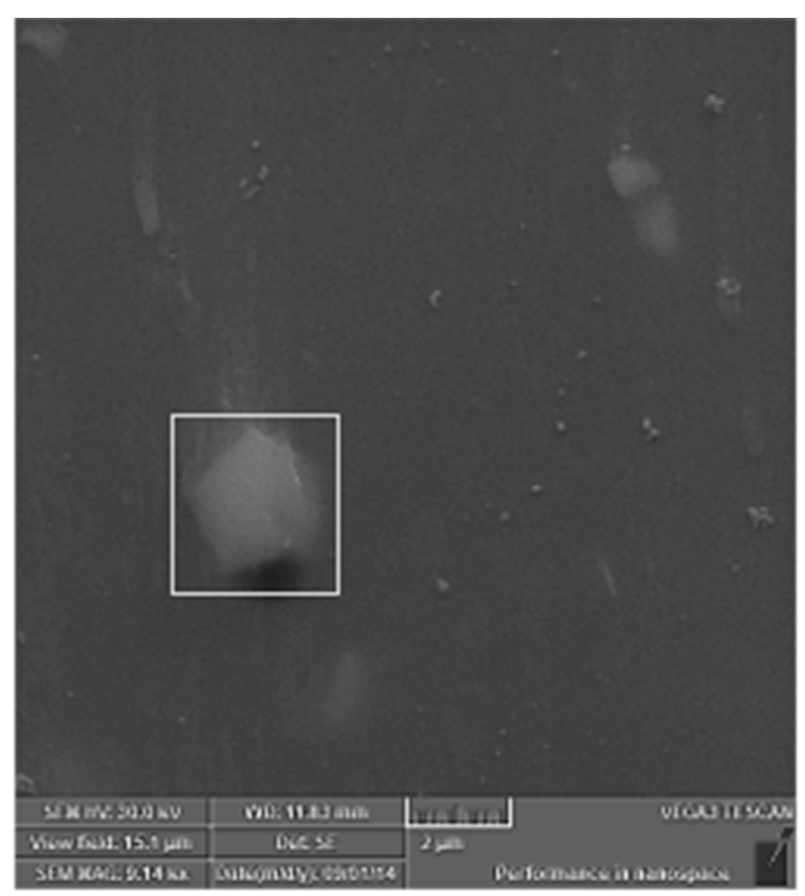

Fig. 6 Detail of analyzed intermetallic phase of sample No.1

Sample No. 1 also exhibited numerous irregular intermetallic phases containing $\mathrm{Fe}$ and $\mathrm{Mn}$ in addition to a large number of $\mathrm{Al}_{3} \mathrm{Mg}_{2}$ - type intermetallic bases as described in the Al-Mg binary system (Fig. 4). In Fig.
4 shows the intermetallic phase detected on a metallographic cut made of sheet No. 1 and is highlighted by a yellow rectangle. Figure 5 shows the spectrum of analyzed elements from the selected area. Quantification of the content of individual elements is given in Table 2. As can be seen from these data, the analyzed intermetallic phase is rich in $\mathrm{Al}, \mathrm{Fe}, \mathrm{Mn}$ and a small amount of $\mathrm{Mg}$ alloying element. It is therefore a complex intermetallic type of AlFeMn $(\mathrm{Mg})$.

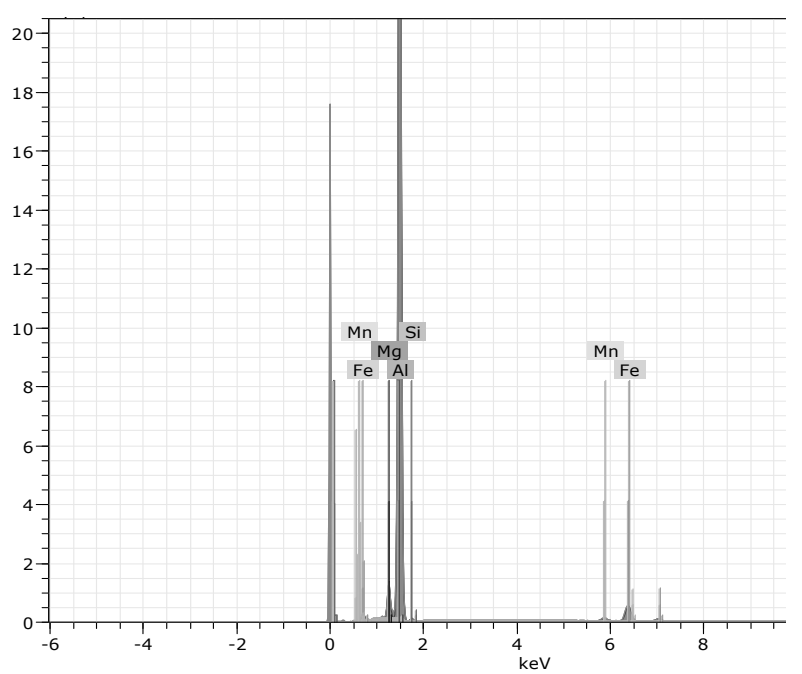

Fig. 7 Spectrum of EDS analysis from sample No. 1

Tab. 3 Quantification of areal EDS analysis from samples No. 1 (area marked in Fig. 4)

\begin{tabular}{|c|c|c|c|c|c|}
\hline 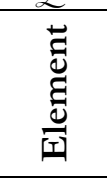 & $\cdot \stackrel{\infty}{\mathscr{D}}$ & $\begin{array}{l}0 \\
\dot{0} \\
\dot{3}\end{array}$ & U & 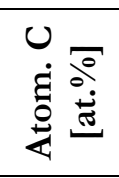 & 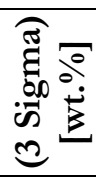 \\
\hline Al & K-series & 93.75 & 89.74 & 92.36 & 14.21 \\
\hline $\mathrm{Fe}$ & K-series & 5.44 & 5.21 & 2.59 & 0.60 \\
\hline $\mathrm{Mg}$ & K-series & 3.50 & 3.35 & 3.83 & 0.74 \\
\hline Mn & K-series & 1.00 & 0.96 & 0.48 & 0.22 \\
\hline Si & K-series & 0.78 & 0.75 & 0.74 & 0.28 \\
\hline Total: & & 104.48 & 100.00 & 100.00 & \\
\hline
\end{tabular}


Another very similar intermetallic phase as in Fig. 4 has been identified in sample No. 1 and is shown in Fig. 6. Figure 6 shows a difference in shape (morphology) of this intermetallic phase, which has more regular geometric shapes than the intermetallic phase in Fig. 4. Figure 7 shows a spectrum of analyzed elements from a selected area. Quantification of the content of individual elements is given in Table 3. As can be seen from these data, the analyzed intermetallic phase is rich in $\mathrm{Al}, \mathrm{Fe}, \mathrm{Mn}, \mathrm{Si}$ and a small amount of $\mathrm{Mg}$ alloying element. It is therefore a complex intermetallic type of $\mathrm{AlFeMnSi}(\mathrm{Mg})$.

\section{Sample 2}

Sample No. 2, in addition to its large number of $\mathrm{Al}_{3} \mathrm{Mg}_{2}$ - type intermetallic bases, as described in the Al-Mg binary system, also exhibited numerous geometric regular plate-like intermetallic phases with a high Fe content (Fig. 8). Figure 9 shows a spectrum of analyzed elements from a selected area. Quantification of the content of individual elements is given in Table 4. As can be seen from these data, the analyzed intermetallic phase is Fe-rich doped with a small amount of Mn. In terms of EDS analysis and stoichiometric ratio between $\mathrm{Al}$ and $\mathrm{Fe}$ and in the absence of $\mathrm{Si}$, this is the intermetallic phase of $\mathrm{AlFe} 3$, which is also illustrated by the shape of the intermetallic phase and the binary diagram of Al-Fe.

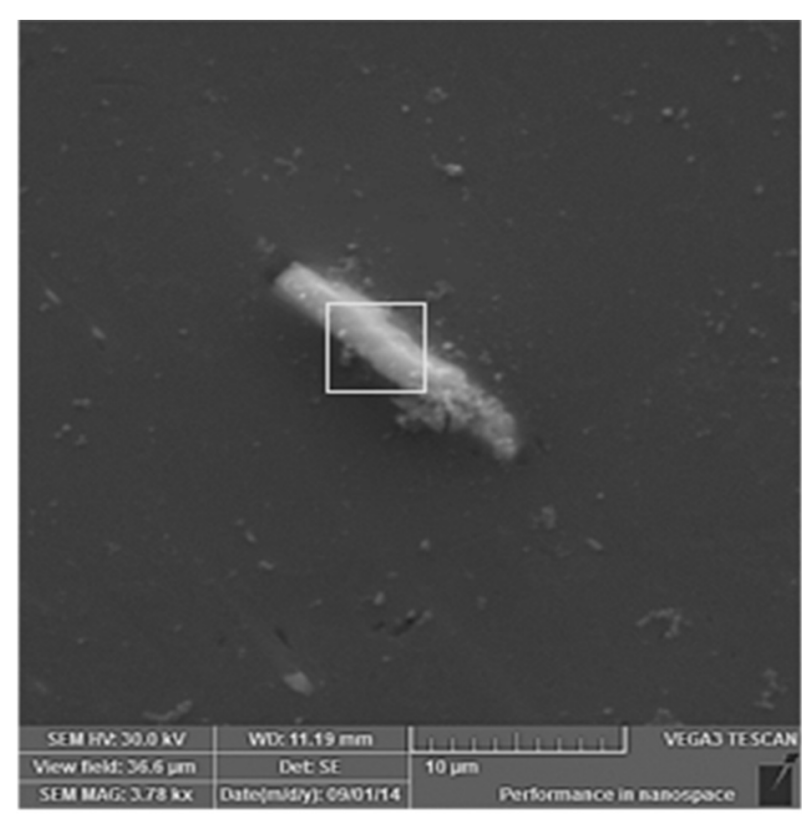

Fig. $\boldsymbol{8}$ Detail of analyzed intermetallic phase of sample No. 2

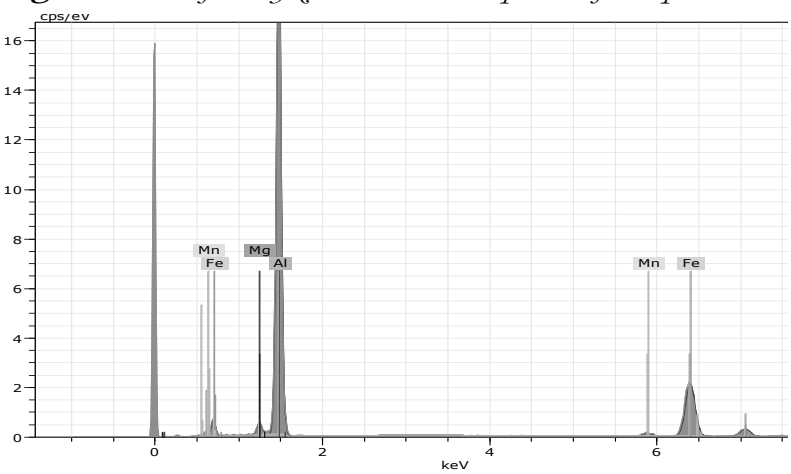

Fig. 9 Spectrum of EDS analysis from sample No. 2

Tab. 4 Quantification of areal EDS analysis from samples No. 2 (area marked in Fig. 6)

\begin{tabular}{|c|c|c|c|c|c|}
\hline 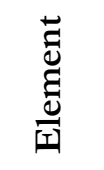 & 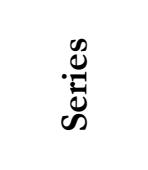 & 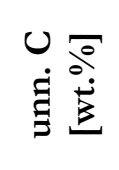 & 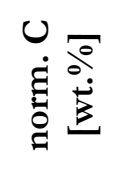 & 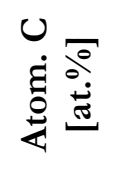 & 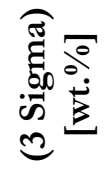 \\
\hline $\mathrm{Al}$ & K-series & 77.92 & 72.93 & 83.33 & 11.89 \\
\hline $\mathrm{Fe}$ & K-series & 25.25 & 23.63 & 13.04 & 2.13 \\
\hline $\mathrm{Mg}$ & K-series & 2.56 & 2.4 & 3.04 & 0.63 \\
\hline Mn & K-series & 1.11 & 1.04 & 0.59 & 0.25 \\
\hline Total: & & 106.84 & 100.00 & 100.00 & \\
\hline
\end{tabular}

Tab. 5 Quantification of areal EDS analysis from samples No. 2 (area marked in Fig. 8)

\begin{tabular}{|c|c|c|c|c|c|}
\hline 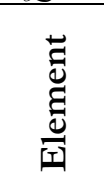 & 胥 & $\begin{array}{l}u \\
\text { 递 }\end{array}$ & 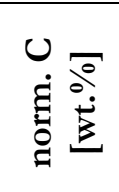 & 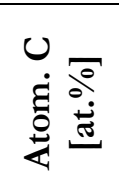 & 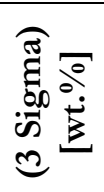 \\
\hline $\mathbf{A l}$ & K-series & 76.68 & 78.35 & 86.33 & 11.76 \\
\hline $\mathrm{Fe}$ & K-series & 16.11 & 16.46 & 8.76 & 1.53 \\
\hline Si & K-series & 0.72 & 0.73 & 0.78 & 0.33 \\
\hline $\mathrm{Mg}$ & K-series & 1.00 & 1.02 & 0.55 & 0.27 \\
\hline $\mathrm{Ni}$ & K-series & 0.85 & 0.87 & 0.44 & 0.28 \\
\hline Total: & & 97.86 & 100.00 & 100.00 & \\
\hline
\end{tabular}




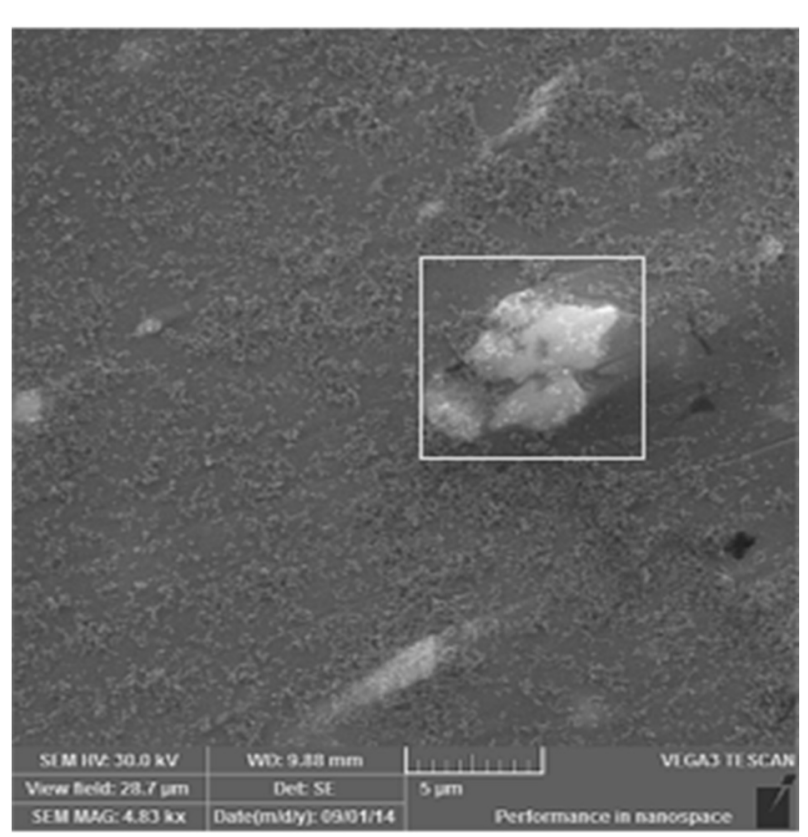

Fig. 10 Detail of analyzed intermetallic phase of sample no. 2

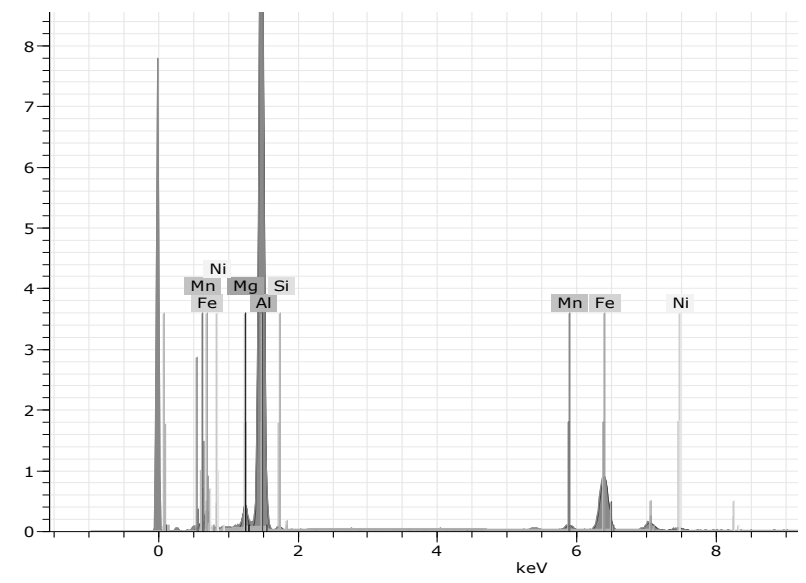

Fig. 11 Spectrum of EDS analysis from sample No. 2

Sample 2 also exhibited unique geometric irregular intermetallic phases with a high Fe content and less $\mathrm{Mg}, \mathrm{Mn}$ and $\mathrm{Si}$ in its structure (Fig. 10). Figure 11 shows a spectrum of analyzed elements from a selected area. Quantification of the content of individual elements is given in Table 5. As can be seen from these data, the analyzed intermetallic phase is Fe-rich doped with a small amount of Mn. In terms of EDS analysis and stoichiometric ratio between $\mathrm{Al}$ and $\mathrm{Fe}$ and in the doping, it is an intermetallic phase of $\mathrm{AlFe}_{4}$. In terms of the presence of $\mathrm{Mg}$ and $\mathrm{Si}$ in EDS analysis and literature sources [1], they may also be complex intermetallic phases of the type $\mathrm{Al}_{4} \mathrm{Fe}_{2} \mathrm{Si}, \mathrm{Al}_{8} \mathrm{FeSi}$ or $\mathrm{Al}_{5} \mathrm{FeSi}$.

\section{Sample 3}

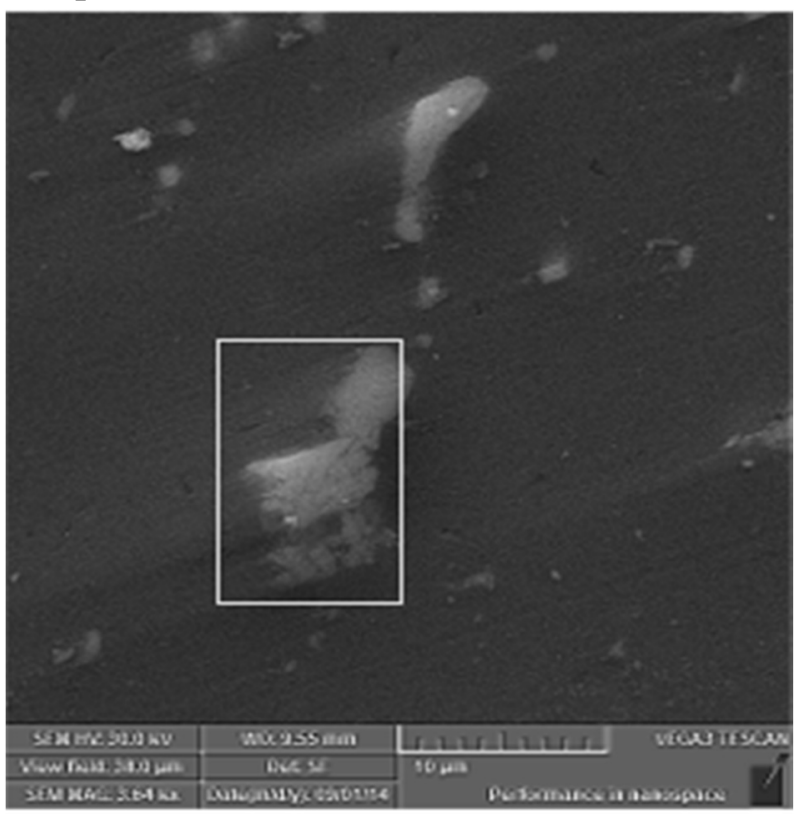

Fig. 12 Detail of analyzed intermetallic phase of sample No. 3

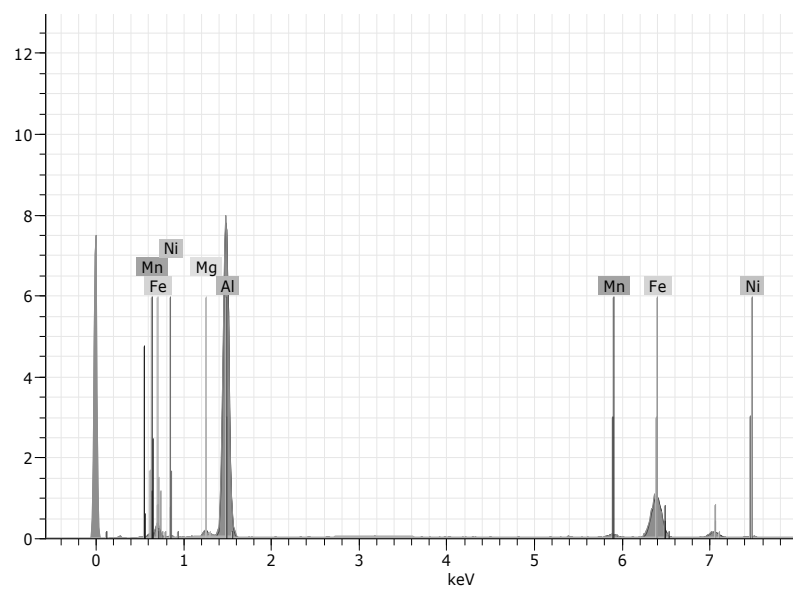

Fig. 13 Spectrum of EDS analysis from sample No. 3

Tab. 6Quantification of areal EDS analysis from samples No. 3 (area marked in Fig. 10)

\begin{tabular}{|c|c|c|c|c|c|}
\hline 苞 & $\cdot \stackrel{\mathscr{D}}{\stackrel{D}{J}}$ & 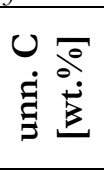 & 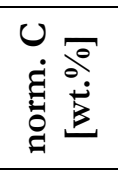 & 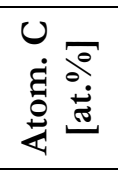 & 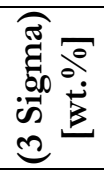 \\
\hline $\mathbf{A l}$ & K-series & 66.76 & 70.58 & 82.20 & 10.50 \\
\hline $\mathrm{Fe}$ & K-series & 23.26 & 24.70 & 13.90 & 2.30 \\
\hline Mn & K-series & 1.41 & 1.49 & 0.85 & 0.40 \\
\hline $\mathbf{M g}$ & K-series & 1.65 & 1.74 & 2.25 & 0.61 \\
\hline $\mathrm{Ni}$ & K-series & 1.40 & 1.48 & 0.79 & 0.45 \\
\hline Total: & & 94.58 & 100.00 & 100.00 & \\
\hline
\end{tabular}


Sample 3 exhibited in its structure besides a large number of basic intermetallic phases of the $\mathrm{Al}_{3} \mathrm{Mg}_{2}$ type, as well as a plurality of geometrically irregular coarse, high - Fe intermetallic phases (Fig. 12). Figure 13 shows a spectrum of analyzed elements from a selected area. Quantification of the content of individual elements is given in Table 6. As can be seen from these data, the analyzed intermetallic phase is Fe-rich doped with a small amount of $\mathrm{Mn}$ and Ni. In terms of EDS analysis and stoichiometric ratio between $\mathrm{Al}$ and $\mathrm{Fe}$ and in the absence of $\mathrm{Si}$, this is the intermetallic phase of $\mathrm{AlFe}_{3}$, which is also illustrated by the shape of the intermetallic phase and the binary diagram of $\mathrm{Al}-\mathrm{Fe}$.

\section{Sample 4}

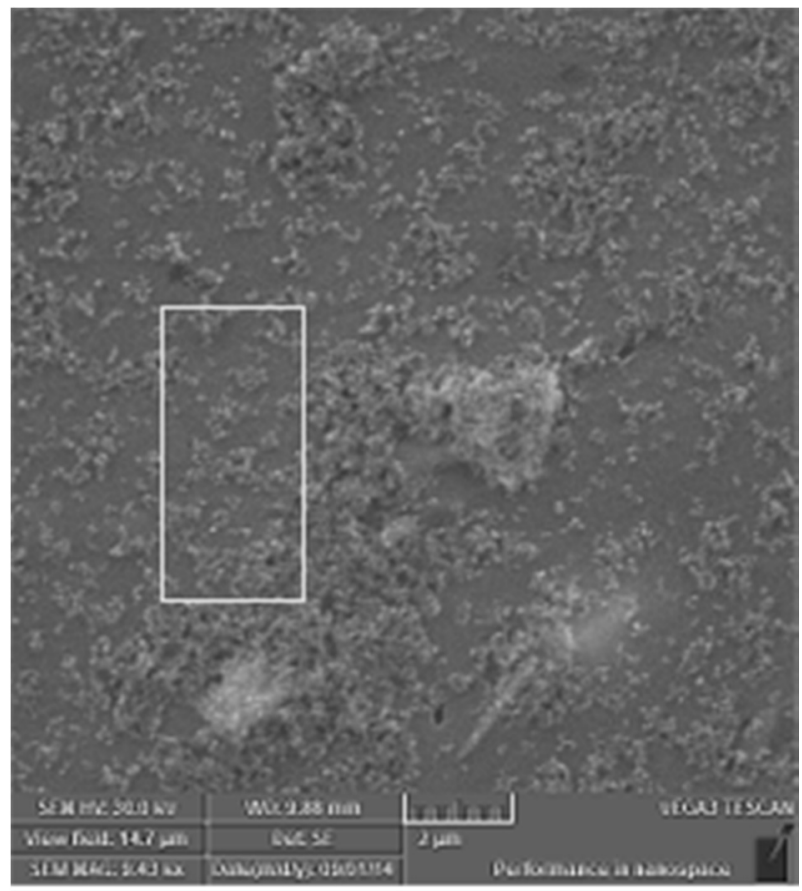

Fig. 14 Detail of analyzed intermetallic phase of sample No.4

Sample 4 exhibited essentially only a large amount of $\mathrm{Al}_{3} \mathrm{Mg}_{2}$-type intermetallic phase as described in the $\mathrm{Al}-\mathrm{Mg}$ binary system and such a very small amount of $\mathrm{AlFe}_{4}$-type intermetallic phase (Fig. 14). Figure 15 shows a spectrum of analyzed elements from a se- lected area of clusters of very fine irregular intermetallic phases. Quantification of the content of individual elements is given in Table 7. As can be seen from these data, the analyzed fine intermetallic phases are $\mathrm{Mg}$-rich and are the intermetallic phase $\mathrm{Al}_{3} \mathrm{Mg}_{2}$, which is also illustrated by the intermetallic phase shape and the Al$\mathrm{Mg}$ binary diagram.

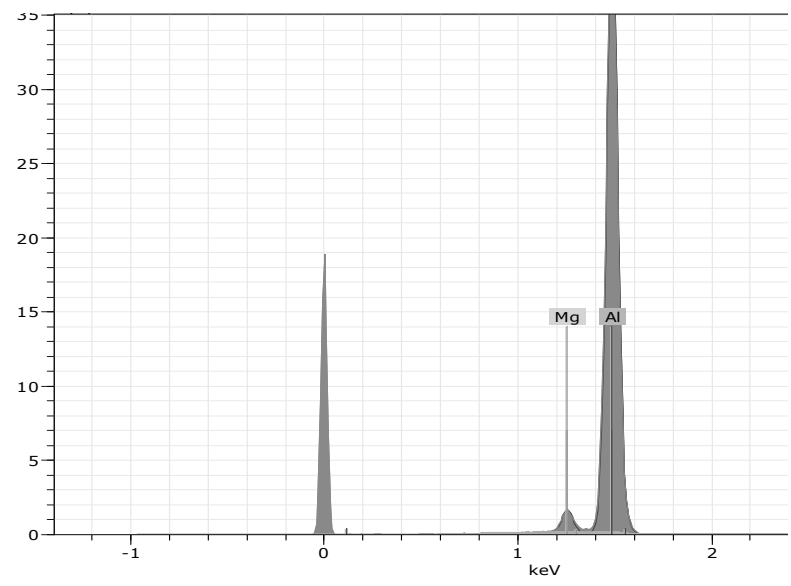

Fig. 15 Spectrum EDS analysis from Sample No. 4

Tab. 7 Quantification of areal EDS analysis from samples No. 3 (area marked in Fig. 12)

\begin{tabular}{|c|c|c|c|c|c|}
\hline 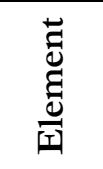 & $\cdot \stackrel{\mathscr{E}}{\mathscr{D}}$ & 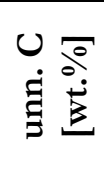 & 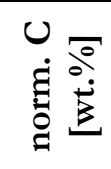 & 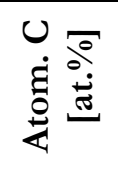 & 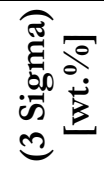 \\
\hline Al & & 82.70 & 96.80 & 96.46 & 12.71 \\
\hline $\mathrm{Mg}$ & K-series & 2.74 & 3.20 & 3.54 & 0.71 \\
\hline Total: & & 85.44 & 100.00 & 100.00 & \\
\hline
\end{tabular}

\section{Static tensile test}

The static tensile test was carried out on the Inspekt 100 tensile testing machine from Hegewald \& Peschke at the parameters defined by ČSN EN 10002 - 1 (420310). The test was performed at normal ambient temperature of $20 \pm 2^{\circ} \mathrm{C}$. The loading speed was set to $4 \mathrm{~mm} / \mathrm{min}$ for all test samples. The results of the static tensile test are recorded in Table 8. As can be seen from Table 8 , the highest tensile strength values are attained by specimens No. 2,3, but have low ductility and the best ductility is shown in sample No. 4 , which contains a minimum of impurities.

Tab. 8 Results of static tensile test

\begin{tabular}{|c|c|c|c|}
\hline Sample number & $\varnothing \mathrm{Rm}[\mathrm{MPa}]$ & $\mathrm{A} \mathrm{[ \% ]}$ & Note \\
\hline 1 & 236.0 & 21.1 & $\begin{array}{c}\text { Average value of } 10 \\
\text { measurements }\end{array}$ \\
\hline 2 & 259.0 & 20.7 & $\begin{array}{c}\text { Average value of } 10 \\
\text { measurements }\end{array}$ \\
\hline 3 & 260.2 & 20.9 & $\begin{array}{c}\text { Average value of } 10 \\
\text { measurements }\end{array}$ \\
\hline 4 & 218.5 & 35.1 & $\begin{array}{c}\text { Average value of } 10 \\
\text { measurements }\end{array}$ \\
\hline
\end{tabular}




\section{Discussion of the results}

Due to the increased content of admixture elements in samples No. 1, 2, 3, mainly Fe, $\mathrm{Mn}$ and Si, numerous intermetallic phases rich in these elements were also detected in their microstructure outside of sample No. 4, where the content of these elements was minimal and complex phases containing these impurity elements were virtually not identified in the structure of this sample.

Sample No. 1 showed an increase in the content of impurity elements $\mathrm{Fe}, \mathrm{Mn}$, and in its structure also in addition to the basic intermetallic phase of the $\mathrm{Al}_{3} \mathrm{Mg}_{2}$ type, it also showed a number of irregular intermetallic phases containing $\mathrm{Fe}$ and $\mathrm{Mn}$. The next identified intermetallic phase in Sample No. 2 in a small amount was the AlFeMnSi $(\mathrm{Mg})$ phase.

Sample No. 2 exhibited, besides a large amount of $\mathrm{Al}_{3} \mathrm{Mg}_{2}$-type intermetallic bases in its structure, and due to the high Fe content $(0.7 \%)$ as an admixture element, also a brittle intermetallic $\mathrm{AlFe}_{3}$ phase. In terms of the presence of $\mathrm{Mg}$ and $\mathrm{Si}$ in sample No. 2, also complex intermetallic phases of the type $\mathrm{Al}_{4} \mathrm{Fe}_{2} \mathrm{Si}$, $\mathrm{Al}_{8} \mathrm{FeSi}$ or $\mathrm{Al}_{5} \mathrm{FeSi}$ were also identified. it is an intermetallic phase of $\mathrm{AlFe}_{4}$.

Sample No. 3 showed in its structure besides a large number of basic intermetallic phases of the $\mathrm{Al}_{3} \mathrm{Mg}_{2}$ type, as well as numerous geometrically irregular, coarse, intermetallic phases with a high Fe content. In terms of EDS analysis and stoichiometric ratio between $\mathrm{Al}$ and $\mathrm{Fe}$ and in the absence of $\mathrm{Si}$, this is the intermetallic phase of $\mathrm{AlFe}_{3}$.

Sample No. 4 had essentially only a large amount of $\mathrm{Al}_{3} \mathrm{Mg}_{2}$-type intermetallic phase as described in the $\mathrm{Al}-\mathrm{Mg}$ binary system and such a very small amount of $\mathrm{AlFe}_{4}$-type intermetallic phase.

The influence of admixture elements, mainly $\mathrm{Fe}$ and also to a lesser extent $\mathrm{Mn}$ on ductility is very obvious. Sample No. 1 shown the tensile strength average value $236 \mathrm{MPa}$ and elongation $21,1 \%$. The sample No. 2 with the tensile strength $259 \mathrm{MPa}$ reached elongation $20,7 \%$. The sample No.3 with the tensile strength 260.2 $\mathrm{MPa}$ and elongation 20,9\%. The last sample No. 4 had a tensile strength average value $218.5 \mathrm{MPa}$ but the has increased to $35.1 \%$.

\section{Conclusion}

Admixture elements in samples No. 1, 2, 3, mainly $\mathrm{Fe}, \mathrm{Mn}$ and $\mathrm{Si}$, numerous intermetallic phases rich in these elements were also detected in their microstructure. Sample No. 4, where the content of these elements was minimal and complex phases containing these impurity elements were virtually not identified in the structure of this sample. All samples showed a large amount of $\mathrm{Al}_{3} \mathrm{Mg}_{2}$-type intermetallic phase as a result of alloying the investigated Mg alloy (about 3\%) and corresponds to the $\mathrm{Al}-\mathrm{Mg}$ binary system.

The influence of admixture elements, mainly $\mathrm{Fe}$ and also to a lesser extent Mn on ductility is very obvious, where in terms of ductility results in samples with the occurrence of brittle intermetallic phases (samples No. 1,2,3) containing Fe and Mn ductility only in range $20-21 \%$ and elongation $35 \%$ for sample No. 4 with a minimum content of these impurities. Decrease of ductility causes consequently impaired formability of the material and brittle intermetallic phases initiate micro-cracks with subsequent cracking of the material.

\section{Acknowledgements}

The article was created as a part of the project support with the support of grant UJEP-SGS2020-48-002-2 in Ústí nad Labem.

The article was created as a part of the project support with the support of grant UJEP-SGS2019-48-001-2 in Ústí nad Labem.

\section{References}

[1] MICHNA, Š. a kol. (2005). Encyklopedie bliniku. 1. Vydání, Prešov, SR: Adin s. r. o., 700 p.

[2] J. BANDYOPADHYAY AND K.P. GUPTA, TRANS. (1970). Phase Relationship and Structural Transformations in Al-Mg System in the Composition Range 39 to 56 at Per Cent Mg. Indian Inst. Met., 23, No. 4, pp. 65-70.

[3] STILLER, W., HOFFMEISTER, H. (1979). Determination of Liquid/Solid Phase Equilibria of Aluminum-Magnesium-Zinc Alloys. Metallk.d., Vol. 70, No. 12, pp. 817-824.

[4] CAIS, J., MICHNA, Š. (2015). Research of Infulence of Heat Treatment on Microstrucrure and Mechanical Propertis of AlSi9CuNiMn Alloy. Manufacturing Technology, Vol. 15, No. 5, pp. 43-46.

[5] MICHNA, Š., CAIS, J., MICHNOVÁ, L. (2015). Research of the Cause Cracking HotRolled Block Made of AlMg5 Alloys. Manufacturing Technology, Vol. 15, No. 4, pp. $614-620$.

[6] HREN, I., MICHNA, Š., MICHNOVÁ, L. (2019). Dependence of mechanical properties on porosity of AlSi7Mg0.3 alloy during gravity casting. Engineering for Rural Development, No. 18, pp. 1001-1006. ISSN: 1691-5976.

[7] MONDOLFO L. F. (1979). Aluminium Alloys, Structure and Properties. Butterworths, London, $986 \mathrm{p}$.

[8] MICHNA, S., KUSMIERCZAK, S. (2012). Praktická metalografie. FVTM UJEP, 245 s., ISBN 978-80-7414- 503-2. 
[9] LUKÁČ, I., MICHNA, S. (2001). Colour Contrast, Strukture and Defects in Aluminium and Aluminium Alloys. Velká Britanie, Cambridge international science publishing, ISBN 18 98326-703.

[10] NOVOTNÝ, J., MICHNA, Š., JANOVEC, J. (2019). Vybrané kapitoly z fyziky kovi a fraktografie, vydavatel UJEP v Ústí nad Labem, 234 p., ISBN 978 - 80-7561-8.

[11] MICHNA, Š., HONZÁTKO, R., CAIS, J. (2013). Analysis of Causes Al2Mg04 - Type Spinel Inclusion Formation in Low-Pressure
Casting. Manufacturing Technology, Vol.13, No. 3, pp. 361-368. ISSN 1213 -2489.

[12] IVA NOVAKOVA, JAROMIR MORAVEC, PAVEL KEJZLAR. (2017). Metallurgy of the Aluminium Alloys for High-Pressure Die Casting. Manufacturing Technology. Vol. 17, No. 5, pp. 804-811. ISSN 1213-2489.

[13] TOMASZ LIPIŃSKI. (2017). Analysis of Mechanical Properties of AlSi9Mg Alloy with Al, $\mathrm{Ti}$ and B Additions. Manufacturing Technology. Vol. 17, No. 5, pp. 761-766. ISSN 1213-2489. 